\title{
REPETITIVE STIMULATION IN THE CENTRAL NERVOUS SYSTEM ${ }^{\star}$
}

\author{
By L. S. Illis, M.D., B.Sc., F.R.C.P. \\ Consultant Neurologist, Wessex Neurological Centre, Clinical Senior Lecturer in \\ Neurology, Southampton University Medical School
}

There has been a considerable change in ideas about the effect of a lesion in the central nervous system (CNS) and the view of a fixed neurological deficit following a lesion in the CNS is no longer tenable. The clinical picture seen after a partial lesion in the CNS depends in part on the destruction or partial destruction of nerve pathways and cells, but is also the result of changes which occur in synaptic zones following degeneration and the triggering off of the sequence of events which includes sprouting of intact terminals and the 'unmasking' of pre-existing, but relatively insignificant, neural pathways. The effect of this is to produce an altered connectivity within the intact CNS. Destruction of a major input would not only have a negative effect but would also have a positive effect of making previously minor inputs relatively more important.

This not only provides a theoretical basis for attempting to improve function in patients with a partial lesion of the CNS, but also suggests that the problem of rehabilitation of such patients should be aimed at the intact but poorly functioning central nervous system, since not only is there evidence of adaptation and reorganisation, even in the adult animal, but there is also evidence of stimulation.

Environmental stimulation produces changes which include expansion of visual cortex, increase in dendritic branching, increase in glia and increase in cholinesterase. In addition to structural changes, environmental stimulation produces behavioural changes.

Experimental electrical stimulation produces changes in synapse size, synaptic vesicle change, dendritic branching and changes in synaptic transmission. Experimental spinal cord stimulation (in cat and monkey) has been shown to alter evoked responses, to produce postsynaptic inhibition, primary afferent depolarisation, increase in Renshaw cell activity and inhibition of monosynaptic activity. In man, spinal cord stimultion produces improvement in cervical and brain stem evoked responses, changes in plasma and CSF catecholamines, changes in $\mathrm{H}$-reflex, and decrease in tonic stretch reflex. The major changes in man, however, are in bladder function where there has been repeated demonstration of improved residual urine, bladder capacity, sphincter EMG, urethral pressure and flow rate.

The best controlled studies have been in multiple sclerosis, where spinal cord stimulation has been used to treat the deficit produced by multiple sclerosis and these changes are given in more detail.

\section{REFERENCES}

Cook, A. W., Oygar, A., Baggenstos, P., Pacheco, S. \& Kleriga, E. (i976). Vascular disease of the extremities: electrical stimulation of the spinal cord and posterior roots. New York State Fournal of Medicine, 76, 366-368.

Devor, M. (I982). Plasticity in the adult nervous system. In: Illis, L. S., Sedgwick, E. M. and Glanville, H. J. (Eds), 'Rehabilitation of the Neurological Patient'. Blackwell Scientific Publications, Oxford.

Hawkes, C. H., Wyke, M., Desmond, A., Bultitude, M. I. \& Kanegaonkar, G. S. (I980). Stimulation of dorsal column in multiple sclerosis. British Medical fournal, 1, 889-89I.

* Abstract of paper read at the Scientific Meeting of the International Medical Society of Paraplegia, Athens, Greece. October 1982. 
ILlIS, L. S. (1973). Regeneration in the central nervous system. Lancet, I, 1035-1037.

Illis, L. S., Read, D. J., Sedgwick, E. M. \& Tallis, R. C. (I982). Spinal cord stimulation in the United Kingdom. F. Neurol. Neurosurg. Psychiat., 46, (in press).

Illis, L. S. \& Sedgwick, E. M. (I982). Stimulation Procedures. In: Illis, L. S., Sedgwick, E. M. and Glanville, H. J. (Eds), 'Rehabilitation of the Neurological Patient'. Blackwell Scientific Publications, Oxford.

Read, D. J., Matthews, W. B. \& Higson, R. H. (I980). The effect of spinal cord stimulation on patients with multiple sclerosis. Brain, I03, 803-833.

Sedgwick, E. M., Illis, L. S., Tallis, R. C., Thornton, A. R. D., Abraham, P., ElNegamy, E., Docherty, T. B., Soar, J. S., Spencer, S. C. \& Taylor, F. M. (I980). Evoked potentials and contingent negative variation during treatment of multiple sclerosis with spinal cord stimulation. F. Neurol. Neurosurg. Psychiat., 43, I 5-24.

Tallis, R. C., Illis, L. S., Sedgwick, E. M., Hardwidge, C. \& Garfield, J. S. (I983). Spinal cord stimulation in peripheral vascular disease. $\mathcal{F}$. Neurol. Neurosurg. Psychiat., 46, (in press). 